Review: Coral Reefs and the Ice Age

Author(s): Arthur Holmes

Review by: Arthur Holmes

Source: The Geographical Journal, Vol. 48, No. 5 (Nov., 1916), pp. 411-415

Published by: geographicalj

Stable URL: http://www.jstor.org/stable/1779617

Accessed: 23-06-2016 11:02 UTC

Your use of the JSTOR archive indicates your acceptance of the Terms \& Conditions of Use, available at

http://about.jstor.org/terms

JSTOR is a not-for-profit service that helps scholars, researchers, and students discover, use, and build upon a wide range of content in a trusted digital archive. We use information technology and tools to increase productivity and facilitate new forms of scholarship. For more information about JSTOR, please contact support@jstor.org.

The Royal Geographical Society (with the Institute of British Geographers), Wiley are collaborating with JSTOR to digitize, preserve and extend access to The Geographical Journal 
Collingwood Bay for the most part were not. Apart from the Gwoira district and the district inland from Mount Lamington, and perhaps a few isolated areas high up in the main range, the country is perfectly safe, and the natives very amenable to Government influence.

A census of some of the coastal villages was taken, and it was found that the number of men exceeded the number of women in the ratio of nearly four to three. It is possible that this may be due to the former prevalence of female infanticide.

\section{CORAL REEFS AND THE ICE AGE.}

The Glacial-Control Theory of Coral Reefs.- Reginald A. Daly. (a) Am. Journ. Sci., vol. 30, pp. 297-308, 1910; (b) Proc. Am. Ac. Arts and Sci., vol. 5I, No. 4, November, pp. 157-25I, I9I5 ; (c) Am. Fourn. Sci., vol. 4I, pp. 167-186, I916.

THE elaborate and ingenious theory of coral reefs of which Prof. Daly 1 is the author was suggested to him in the approved scientific manner that begins with the observation of facts. In r 909 he noticed the narrowness-and therefore the youthfulness-of the coral reefs fringing the Hawaiian Islands. Connecting this youthfulness with the discovery that a former glacier had left its traces on the' flanks of Mauna Kea, he came to the conclusion that corals could not have flourished along the Hawaiian shores during the Glacial period, and that the existing reefs must have developed during post-Glacial time. An extension of the principle here involved to all the coral reefs of the Earth's surface led to the theory outlined below.

At the present time the range of temperature in the surface waters of the coral seas is from $23^{\circ} \mathrm{C}$. to $29^{\circ} \mathrm{C}$. according to the locality and the season. Remembering that $20^{\circ} \mathrm{C}$. is the lower limit for coral growth, it is clear that a fall of a few degrees would in many places lead to the extinction of corals that now flourish vigorously. During the Glacial period, in which both hemispheres seem to have suffered roughly contemporaneous glaciation, the lowering of the snow-line amounted to roo0-2000 metres, and this fact, according to Daly's calculations, implies a fall of ocean temperatures near the surface of from $5^{\circ} \mathrm{C}$. to $10^{\circ} \mathrm{C}$. For this reason it is deduced that many pre-existing coral reefs were killed, leaving only a few sheltered spots where the uninterrupted propagation of corals could proceed, afterwards, when the rigour of climatic conditions had abated, to spread and colonize the shoals and platforms on which the active reefs of the present day are founded.

A second consequence of the Glacial period is no less significant for coral-reef theory. At the present time it is considered that existing icecaps represent a transference of water from the oceans equivalent to a total 
lowering of the surface by I I to 37 metres. During the climax of glacial conditions the total lowering of the surface may have been 60 to 140 metres according to the assumptions made. Considering all the evidence Daly concludes that the ocean-level was then 50 to 60 metres lower than now on account of the removal of water to form ice-caps. In addition to this there may have been a gravitative withdrawal of water from tropical seas due to the attraction of ice-caps in high latitudes. This component of lowering is estimated as averaging ro metres, giving a total of 60 to 70 metres at the time of maximum glaciation.

As a result of the lowered sea-level, and the lack of protecting rims of growing coral, pre-glacial islands and reefs would be steadily attacked by the waves, and in many cases reduced by marine abrasion to platforms a few metres below the sea-level of the period. It is not likely that abrasion proceeded to depths averaging much more than 20 metres below the lowered sea-level, and Daly suggests 40 metres as a maximum depth, giving as the maximum limits for the present depth of submarine platforms, 80 to I ro metres. According to Daly, and Vaughan $(A m$. J. Sci., 4r, p. I 3 I, I9r6), and many of the earlier writers on coral reefs, Tyerman and Bennet, Wharton, Agassiz, and others, the problem to be solved is essentially the problem of the origin of the platforms. Vaughan, in particular, is convinced that the platforms antedate the development of reefs, and his work, together with that of Drew and Kellerman, has demonstrated the inability of solution as a means of developing the lagoons of barrier reefs and atolls. Daly has collected a large mass of statistical data bearing on the dimensions and depths of reef platforms, and from them he has drawn forty-three excellent sections of various types of reefs and lagoons. His figures illustrate the following generalizations :-

(a) Lagoon depths (both average and maximum) increase with the widths of the platforms ; that is to say, the post-glacial deposition of sedimentary veneer within the lagoons is greatest in the case of the smaller examples.

(b) Atoll and barrier lagoons of similar dimensions have depths of the same order (maxima 94 and 9I metres respectively).

(c) The lagoons of "drowned" atolls and the platforms of rimless banks are deeper than those of normal atolls, for where coral growth is restricted by climatic conditions, and so does not reach the surface ("drowned" atolls), or where corals have not gained a footing at all (rimless banks), the calcareous veneer of detritus is necessarily not so thick as when a vigorously growing reef surrounds the lagoon (maxima I Io and I28 metres).

(d) The general range of depths for the larger lagoons is from 60 to 90 metres.

(e) The coral-free portion of the shelf of the Great Barrier Reef of Australia, and many isolated banks outside the coral seas, have closely similar depths. 
Remembering that the smaller lagoons are shallowed by deposition of coral detritus, the depths listed are of the same order as those computed for wave-formed benches formed during the Pleistocene. Day's theory thus withstands a searching statistical test, and his figures bring out the extraordinary flatness of lagoon floors; a feature that, combined with the general accordance of their depths, is considered (as it was by Wharton many years ago) to be fatal to the Darwin-Dana theory of subsidence. It must not be thought, however, that Daly ignores altogether the effects of earth movement, for in many districts, notably those of the south-western Pacific, subsidence and elevation are proved indubitably to have occurred. The statistical data in these cases show that-

(a) uplifted islands either lack submarine shelves, or have shelves at depths differing from those computed for Pleistocene wave-benching by the amount of uplift plus the thickness of sediment since deposited;

(b) subsided islands have shelves at correspondingly greater depths.

Having explained the origin of the platforms, their colonization by reef corals after the final Glacial climax and the upbuilding of the reefs are comparatively simple matters to understand. Known facts concerning the upward and lateral growth of corals, and the period elapsed since the withdrawal of glacial conditions, indicate that the corals have had ample time to keep pace with the rising sea-level, and when the present level was once attained to develop to their present dimensions. In short, Daly explains the growth of fringing and barrier reefs and atolls not by subsidence of oceanic islands, but by a gradual rise of sea-level as the ice stored up during the Pleistocene was slowly melted and liberated.

A number of objections to the glacial-control theory may now be briefly considered. It is generally accepted that the great ice-caps of the Pleistocene did not reach their climax simultaneously. Thus an element of doubt is introduced into Daly's estimate of the lowering of tropical sealevel, which should tend to be too high. However, against this it may be noticed that while the lowering may have been greater than 140 metres (if maximum glaciation was everywhere simultaneous) Daly assumes a depth of only 50 to 60 metres.

It has been argued by Gregory (Nature, 97, p. I9I, I9I6) that the submergence of Scandinavia, Britain, and Labrador, during the Glacial period, would also lower the sea-level. W. M. Davis, on the other hand (Bull. Am. Geog. Soc., 46, p. 729, I914), suggests that such submergence was presumably compensated by an uplift of the neighbouring sea-floor which would tend to raise the sea-level. Clearly, as Daly points out, the depression of these lands does not affect the order of magnitude of the amount of lowering of tropical sea-level assumed by him.

The glacial-control theory implies an abundance of drowned valleys along coasts which have not been glaciated or recently uplifted. The corresponding facts were realized in $\mathrm{I} 894$ by Penck, who explained them by the melting of Pleistocene ice, in preference to assuming subsidence. 
It remains true, of course, that vast lengths of coast show no sign of recent rise of sea-level (Gregory, loc. cit.), but surely this is largely due to the susceptibility of continents to isostatic uplift. Oceanic islands, on the contrary, are generally too small to be affected by isostatic movement, but such movement where it has taken place should generally be in the direction of subsidence.

W. M. Davis has discarded the glacial-control theory for two outstanding reasons of a topographic nature. First, he says (Proc. Nat. Acad. of Sci., vol. I, p. 149, I915), ". . . if the lagoons of large atolls have been abraded across their whole diameter of 20 or 30 miles, the central volcanic islands within narrow-lagoon barrier reefs should have been strongly cliffed by the lowered sea all round their shores," and continuing, he states that this is not the case. Daly admits that most of the cliffs are only a few metres in height, but he points out that if the sea-level were 55 metres below its present level, the cliffs then formed would have to be more than 55 metres in height in order that the upper parts of them should now be visible. Secondly, Davis, following Dana, regards the drowned erosion valleys of volcanic islands as proofs of subsidence, and shows that on the subsidence theory the still unsubmerged portions of the valleys should be of the one cycle type, while on the glacial-control theory the drowned valleys should generally be of the two cycle type, producing a valley-in-valley landscape. But, he says, "in the hundreds of embayments that I saw, no such composite valleys occurred." To this criticism, Daly replies that the physiographic development of volcanic islands is abnormal compared with the continental standard, and that even were an inner valley to have been formed, it is unlikely that the "edge," or break of slope produced by the revived streams, would have been preserved till the present day. "Post-Kansan time, favoured by the rapid rock-decay and heavy rains characteristic of the tropics, seems long enough to have largely or quite obliterated such minute features as these valley-in-valley ' edges.' "'

The glacial-control theory seems to explain satisfactorily a number of features in the submarine topography of coral reefs that are difficult to understand on the subsidence theory of Darwin. Yet there remain certain areas, particularly the south-western Pacific, which are admittedly unstable, and in which Darwin's theory, slightly modified, is "sufficient to account for the reef phenomena" (Marshall, "Oceania," p. 7, I9I 2, in 'Handbuch der Regionalen Geologie'). Vaughan, though sympathetic towards Daly's views, and insisting on the priority of the platform, concludes that coral reefs depend on "some diastrophic change in the earth which has resulted in the sea overflowing the marginal land areas in geologically recent time."

There can be little doubt that controversy will rage for many years on the problem, or rather on the group of problems, presented by the origin of coral reefs, for at present the data are still insufficient to provide an 
adequate basis for a complete explanation. Darwin's theory invokes widespread earth movements about which we still know very little. Daly's theory involves the Glacial period, as to the cause of which we are in total ignorance. Indeed, it is interesting to note that in a recent paper on the cause of the Ice Age (Bull. Geol. Soc. Inst. Univ. Upsala, vol. I3, i. I9I6) Enquist suggests that the great extension of glaciated areas in the Pleistocene was due to a tectonic sinking of the level of the sea to the extent of 600 metres, and the puzzling features of coral reefs are brought forward to support the theory. Daly's cart is Enquist's horse, but as we do not really know which is cart and which its horse, it is impossible to decide which should come first in the links of causation, the Glacial period or the sinking of the seas.

In the present stage of investigation the only theories that call for serious discussion are Darwin's and Daly's. Neither holds the field completely, nor is it likely that they ever will do so, for it would seem wisest to regard them as complementary, each supplying, in any particular case, the defects or inadequacies of its partner. One should not omit to mention that the Glacial-control theory, independently of its truth or otherwise, is worthy of a hearty welcome as a stimulus to further researches. From the causes of the Ice Age, to the habits of reef-building corals, it arouses interest in a wide variety of problems whose solutions, one and all, lie in the future.

AR'THUR Holmes.

\section{THE INDO-RUSSIAN TRIANGULATION CONNECTION.}

オ $\mathrm{E}$ have lately received an important volume, ' Records of the Survey of India,' Vol. 6, prepared under the direction of Colonel Sir S. G. Burrard, Surveyor-General of India, and dealing with the completion of the link connecting the triangulations of India and Russia. The Indian Survey has done much splendid work, but none has been carried out under greater difficulties than this, and none is likely to be more valuable. It is the first step to the final solution of important geodetic problems.

During the International Geodetic Conference of I909, which met in London, the question of a triangulation connection between India and Russia was discussed, and it was suggested that a link might be effected across the northern boundary ranges of India to the Chinese or Russian Pamirs. In the early part of the year I91 I the Surveyor-General of India received a proposal to this effect, and steps were at once taken to organize the work.

In I909-I9I I Gilgit had been connected with Rawul Pindi and the Indian system. In the mean time work on the Russian side, which had been initiated by Colonel Tcheikine, had reached the neighbourhood of 